Personalidade Acadêmica Homenageada:

Raymundo Juliano Feitosa (Universidade Federal do Rio Grande do Norte - UFRN)

\title{
MEDIAÇÃO NA ADMINISTRAÇÃO PÚBLICA: POSSIBILIDADES E LIMITES À RESOLUÇÃO DOS CONFLITOS
}

\section{MEDIATION IN PUBLIC ADMINISTRATION: POSSIBILITIES AND LIMITS FOR CONFLICT RESOLUTION}

\section{VIVIANE DUARTE COUTO DE CRISTO}

Mestre em Direito empresarial e cidadania pelo Centro Universitário Curitiba UNICURITIBA. Especialista em Administração Pública pela Unibrasil. Membro do Grupo de Pesquisa Centro Universitário Curitiba - UNICURITIBA. Professora da Faneesp. Mediadora judicial em formação - TJPR. Advogada. viviane@duartecristo.com.br

\section{RESUMO}

A adoção de métodos alternativos ou adequados na solução de conflitos tem sido estimulada visando a redução do número de processos. Também pode obter maior qualidade nos julgamentos, possibilitando o acesso à justiça, em prazo razoável, àqueles casos em que as partes não possuem condições ou não podem resolver seus problemas mediante autocomposição. Conforme dados do CNJ, no final de 2017 o Poder Judiciário contava com um acervo de 80,1 milhões de processos em andamento, com uma taxa de ampliação média anual de $4 \%$, o que demonstra a necessidade de abertura de novas portas (sistema multiportas) para a resolução das controvérsias além da sentença, que nem sempre trará melhora nas relações entre as partes, até porque a demora na tramitação processual, cuja média na justiça comum de primeiro grau é de três anos e sete meses, propicia um elevado custo econômico e emocional aos envolvidos. O novo CPC passou a disciplinar que estas alternativas deverão ser estimuladas por juízes, advogados, defensores públicos e membros do 


\section{Personalidade Acadêmica Homenageada:}

Raymundo Juliano Feitosa (Universidade Federal do Rio Grande do Norte - UFRN)

Ministério Público (Art. 3 $3^{3}$ o do CPC). Mas foi com a edição da Resolução 125/2010 CNJ, regulamentando, no âmbito judicial a mediação e da conciliação, que tais práticas surgem como um novo paradigma, uma alternativa, uma outra porta, para que os conflitos sejam tratados de forma mais humana, tendo como principais pressupostos: a cultura da paz, a comunicação não violenta, a autorresponsabilização e fortalecimento das partes, e o não julgamento. O procedimento de mediação por sua vez envolve os princípios da independência, da imparcialidade, da autonomia da vontade, da confidencialidade, da oralidade, da informalidade e da decisão informada. Basta saber se a mediação se aplica aos conflitos que tiverem como parte a Administração Pública, que em regra envolvem direitos tidos como indisponíveis em razão da supremacia do interesse público; eis o escopo da presente pesquisa, que se encontra em fase inicial, com a coleta de dados e a proposição de questionamentos e hipóteses para serem desenvolvidas, especialmente com o estudo de caso relativo ao Município de Porto Alegre. Referido Município, de forma pioneira, criou Centros de Mediação e Conciliação em seu âmbito de atuação, seguindo a exigência do Art. 174 do CPC ao dispor que: "A União, os Estados, o Distrito Federal e os Municípios criarão câmaras de mediação e conciliação, com atribuições relacionadas à solução consensual de conflitos no âmbito administrativo". O método até então adotado para a pesquisa é o dedutivo, partindo-se dos pressupostos legais e da doutrina, em confronto com as experiências já desenvolvidas em mediação pelo Município de Porto Alegre, visando a identificação da problemática e das possíveis respostas, especialmente no que tange às possibilidades e limites na sua utilização quando o conflito envolver o poder público, suas particularidades e seu regime de direito público.

PALAVRAS-CHAVE: Mediação; métodos adequados à solução de conflitos; Administração pública; supremacia do interesse púbico. 
Personalidade Acadêmica Homenageada:

Raymundo Juliano Feitosa (Universidade Federal do Rio Grande do Norte - UFRN)

\section{REFERÊNCIAS}

DIAS, Luciano Souto; FARIA, Kamila Cardoso. A mediação e a conciliação no contexto do novo código de processo civil de 2015. Revista Jurídica. Curitiba, v. 03, n. 44, p. 597-630, 2016.

DIAS, Maria Tereza Fonseca. A mediação na Administração Pública e os novos caminhos para a solução de problemas e controvérsias no setor público. Revista Direito do Estado. n. 151, 2016, disponível em: $<$ http://www.direitodoestado.com.br/colunistas/maria-tereza-fonseca-dias/amediacao-na-administracao-publica-e-os-novos-caminhos-para-a-solucao-deproblemas-e-controversias-no-setor-publico>. Acesso em 04 jun. 2019.

NEIVA, Geisa Rosignoli. Conciliação e Mediação pela Administração Pública. Rio de Janeiro: Lumen Juris, 2019.

PALMA, Juliana Bonacorsi de. Sanção e acordo na Administração Pública. São Paulo: Malheiros, 2015.

TARTUCE, Fernanda. Mediação nos conflitos civis. São Paulo: Método, 2018.

VASCONCELOS, Carlos Eduardo de. Mediação de conflitos e práticas restaurativas. São Paulo: Método, 2008. 